Int. J. Dev. Biol. 54: 1597-1607 (2010)

doi: $10.1387 / \mathrm{ijdb} .103262 \mathrm{jc}$

\title{
Virus, development and pluripotent stem cells An interview with Rudolf Jaenisch
}

\author{
JOSÉ B. CIBELLI* \\ Cellular Reprogramming Laboratory, Michigan State University, Michigan, USA
}

\begin{abstract}
Rudolf Jaenisch explains how the quest for an answer to the simple question of viral tropism in the mouse lead him to a life-long career in regulation of gene expression in the early embryo and pluripotent stem cells. He shares his experience about what it takes to develop into a successful scientist; expresses his concern about the challenges facing young scientists entering the field - not all of them funding related - and candidly offers some solid tips on opportunities to take advantage of and mistakes to avoid. Being mindful of when to let go of a project, and staying focused on what is important, are probably obvious tips, but they need to be re-stated, since they also appear to be the most difficult to accomplish. Dr. Jaenisch continues to work tirelessly on the problem of epigenetic control in the early embryo and its connection with stem cells.
\end{abstract}

KEY WORDS: Jaenisch, viral tropism, success pluripotent stem cell, epigenetics

"One should not be doing projects because they give rise to a paper; rather, do that project which really excites you and assume the risk that it may not work out.."

Rudolf Jaenisch

I practically grew up reading Rudolf Jaenisch papers! Well... I am not that young, so let me start again, I did my doctoral degree relishing every new article that came out of Rudolf's lab and so did many of my peers - although they may not say it so explicitly. Considering that every other person working in the field of reprogramming and stem cells wants 'a piece of him' - not to mention members of his lab - I was not sure he would have time for us. As it turned out, it was not too difficult to schedule a meeting. So in the middle of a cold January day I made my journey to Cambridge, MA, USA. Rudolf's office at the Whitehead is in a corner on the $4^{\text {th }}$ floor, modern and bright, with great windows overlooking the MIT campus. Rudolf welcomed us with a big smile and his first suggestion was to go get some coffee at a Starbucks nearby. After he got his cappuccino with soy milk, we settled for a chat that was to last almost three hours. We talked about his career, the direction of science and issues of mentorship. He did not hold back. I must thank him profusely for taking time from his busy schedule to do this and I hope he enjoyed it as much as I did.

Let's begin by talking about your early years and why you chose medicine as a profession.

My father was a doctor and I wanted to study medicine, and he didn't like that. He thought I should do something else, but of course he let me do what I wanted and I ended up studying medicine. And though it were the preclinical studies I liked, when I started clinics in Munich, I did not like it, I really hated it.

\section{Did you see patients?}

No, the university was totally overcrowded. You could never get into lecture rooms. I therefore decided I don't want to go into lecture rooms but just learn medicine from books and rather get into an experimental thesis.

So could you do that, just read from the books and take the exam?

Yes, I spent all my time in the lab and worked on bacteriophages, small bacterial viruses.

\section{Who was your advisor?}

He was Peter-Hans Hofschneider, Max Planck director in Munich. In the 60's in Germany his lab was one of the few that worked in the new field of molecular biology focusing on phages and bacteria. I got in his lab and I really loved it. I passed my

\footnotetext{
Abbreviations used in this paper: $\mathrm{ES}$, embryonic stem cell; iPS, induced pluripotent stem cell; MEF, mouse embryonic fibroblast; MIT, Massachusetts Institute of Technology; M-MuLV, Moloney murine leukemia virus; PI, principal investigator; SCNT, somatic cell nuclear transfer.
}

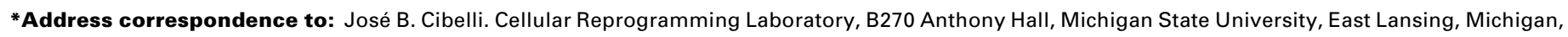
48824 USA. Fax: +1-517-4328742. e-mail: cibelli@msu.edu - web: www.reprogramming.net

Final author corrected PDF published online: 23 February 2011.

ISSN: Online 1696-3547, Print 0214-6282

(C) 2011 UBC Press

Printed in Spain 
exams, I got my MD, and then I went for a postdoc to the US as almost all of my friends did. I got accepted into Arnie Levine's lab in Princeton and became his first PostDoc.

\section{Wasn't that scary to be in a new lab with a new PI?}

I didn't know that. I only knew that he worked with the tumor virus SV40. SV40 DNA is of the same size as the bacteriophage M13 DNA that I had been working with during my thesis. The DNA of M13 and SV40 were both circular making it easy for me to work on SV40 DNA replication. Princeton was an amazing experience for me; it was a pretty old University, with old buildings and rather primitive equipment but with a terrific atmosphere. After four weeks Arnie told me, "By the way, I'm going to Europe on sabbatical, you run the lab." I was pretty shocked.

\section{How old were you?}

I was about 28. I was intimidated, but what was I going to do? We started working.

\section{Did you have a theme?}

SV40 DNA Replication, a topic I was familiar with. Arnie was far away in Europe and there was no e-mail. So I was all-alone, but I think we did some interesting work. But, I was really more interested in malignant transformation by SV40 than in DNA replication. SV40 is a tumor virus that induces sarcomas when injected into mice. This was of great interest as it promised to give insight into mechanisms of cancer.

\section{So back then when you were gone, you were gone.}

Oh yes, I could only talk to Arnie by letter, not even by phone. When he came back we - some of his students and myself - had worked hard and gotten the data for a Naturepaper on SV40 DNA replication. But what puzzled me most was the viral tropism: when you infect mice with SV40, you induce a sarcoma... why not a liver or brain tumor? I thought, either the virus couldn't infect the liver and brain cells, only the skin cells or it can infect all but cannot transform them. How could one distinguish between these possibilities? At that point I read a 1967 paper from Beatrice Mintz, published in PNAS, where she had generated striped mice by aggregating embryos from pigmented with embryos from albino mice. She argued from the number of stripes that the pigment system is derived from 17 primordial melanoblasts on each side of the midline. It's an amazing paper. The paper is easy to read but difficult to understand and I use it every year in class because it forces students to think about embryology. It always creates an interesting discussion. But what caught my attention at the time was not the embryology, which I did not understand, but the approach to manipulate an early embryo in the culture dish and then make a mouse. I was just blown away being a simple molecular biologist. I thought if you could introduce the viral DNA into an early cleavage embryo and generate a mouse, the DNA

\section{Rudolf Jaenisch Professional Milestones at a Glance}
1996 Boehringer Mannheim Molecular Bioanalytics Prize
- 2001 First Peter Gruber Foundation Award in Genetics;
2002 Robert Koch Prize for Excellence in Scientific Achievement;
- 2003 Charles Rodolphe Bruphacher Foundation Cancer Award;
2003 Member, National Academy of Sciences;
- 2006 Max Delbrück Medal for Molecular Medicine;
- 2007 Vilcek Foundation Prize for Achievements of Prominent Immigrants;
2008 Meira and Shaul G. Massry Prize;
2009 Schering price. 


\section{Were these pronuclear injections?}

No, I injected blastocysts and then I transplanted these into foster mothers. I remember when I tried to transplant embryos for the first time I thought it would never work and I transplanted 30 embryos into one female, that's a lot, and I thought if only one survives, it would be a success. But the mouse was getting bigger, bigger, bigger. I was afraid she would explode, and I interrupted the pregnancy: there were 29 embryos. Then I did the real experiment, I injected DNA into embryos and transplanted reasonable numbers into females.

\section{What strain were you using?}

Several different strains such as BALB/C and 129. I got mice that, disappointingly, looked normal raising the question: did they carry SV40 DNA, did the experiment work? This was a difficult question to answer, it was in the 70's, and there was just no method available to probe for such sequences, something that is trivial today. Back then there was not PCR, there was no Southern blot, you couldn't even buy labeled triphosphates. Nothing. But I had to look for SV40 DNA to see if the experiment had worked at all! I decided to cut off the ears of the mice and isolate fibroblasts in culture. When stained for T antigen, I remember this so well, all were positive. I was high for one night. The next morning I stained the control cells and they were also all positive! It was just a crappy antibody (chuckles). I didn't know what to do with these animals - until I got my first job at the Salk Institute.

\section{You did all the work and you didn't have the answer?}

No... Mintz shipped the mice to Salk. There I was really lucky because Paul Berg and Peter Rigby had just invented nick translation, which allowed for the first time to make hot DNA probes. They gave me their unpublished protocol. Tony Hunter showed me how to make labeled triphosphates by "pre-biotic melt": you start with $200 \mathrm{mCi}$ of P32 and end up with $0.5 \mathrm{mCi}$ of hot triphosphate to generate a hot SV40 probe by nick translation which is then used in Cot curves to detect SV40 sequences in genomic DNA. I killed the mice, performed the Cot analyses and indeed detected SV40 sequence in their brains, livers, kidneys and other tissues. This was an absolutely clear-cut result. The experiment convincingly showed that these mice had viral sequences in their genomic DNA. They were the first transgenic mice though the name 'transgenic' was not coined as yet. But there were two issues that bothered me: the mice did not get tumors - epigenetic silencing of viral sequences had not yet been discovered - and I couldn't get germline transmission because I did not realize that the mice were highly mosaic. The breeding experiment was not done in the right way, in hindsight.

\section{How come they were mosaic?}

Because the viral DNA had integrated not in the zygote genome but into blastomeres at a later stage. To see germ transmission would have required a much more extensive breeding of the mice than I did.

Frankly, you were NOT trying to make the first transgenic, you were trying to answer a specific scientific question.

Yes, I have answered the question, the DNA was there but, disappointingly, there were no tumors at all. Of course I didn't understand the epigenetics behind all this. I thought that maybe
SV40s was the wrong virus. At this point, Inder Verma and Hung Fan, two postdocs from David Baltimore's lab at MIT joined the faculty of the Salk and they brought the Moloney leukemia virus (M-MuLV) system. Infection with Moloney leukemia virus induces robust leukemia in mice, which made it attractive for me to use. With help from Hung and Inder, I began to study how to infect embryos. I didn't know whether one needed to remove the zona pellucida by pronase, which might destroy the viral receptors. Also, Koprowski had published that SV40 and Moloney virus can replicate in early embryos, a result I could never repeat which worried me. I removed the zonae (pellucidae) with pronase, as Mintz has done for generating chimeras and infected the embryos at the 4-8 cell stage with virus and got mice. Did they carry Moloney sequences? There was a biological plaque assay for leukemia viruses where XC cells that express the viral envelop fuse upon exposure to infectious virus. This test as well as Cot curves demonstrated that these mice carried viral sequences, which induced leukemia. Most importantly, when bred with normal animals, the mice transmitted the leukemia to $50 \%$ of their offspring. Thus, these were the first animals that transmitted foreign sequences to their offspring according to Mendelian expectations (the experiment is outlined in the cartoon).

\section{And you were the only author in that paper!}

Yes, this was the follow up paper on a first one where we showed the generation of mice without germ line transmission. I did all these later experiments myself.

\section{But when you say "we," you were the only one!}

The first paper on SV40 was with Mintz, which she had communicated to PNAS. With the SV40 transgenic mice, we could not show germline transmission. This was only achieved in the follow up experiments and with the great help I had from Hung Fan and Inder Verma in setting up the Moloney virus system. The results were really exciting.

\section{That's a lot of work to really show that that's what it is.}

Yea, but I had much help and I was so lucky.... First Arnie (Levine) who is a very impressive scientist and was extremely generous to let me do whatever I wanted. And then Mintz: I learned from her about mammalian development, getting the feel for embryos and how to use mouse genetics, and then at Salk where people with very different expertise helped me: Tony Hunter, Inder, Hung and Paul Berg. For example, in my paper with Mintz in 1974, I had to publish the nick translation procedure three years before Berg and Rigby did, and Berg allowed me to do this without being an author!

\section{Do you think those were different times?}

Yes, they were generous, telling me "you can do your own thing."

\section{You wouldn't find that now.}

Probably not. Paul Berg was very generous.

\section{Why didn't you stay at the Salk?}

I got an offer from Germany; I did not think much about it as I didn't know what I really wanted to do. In Hamburg I had to 


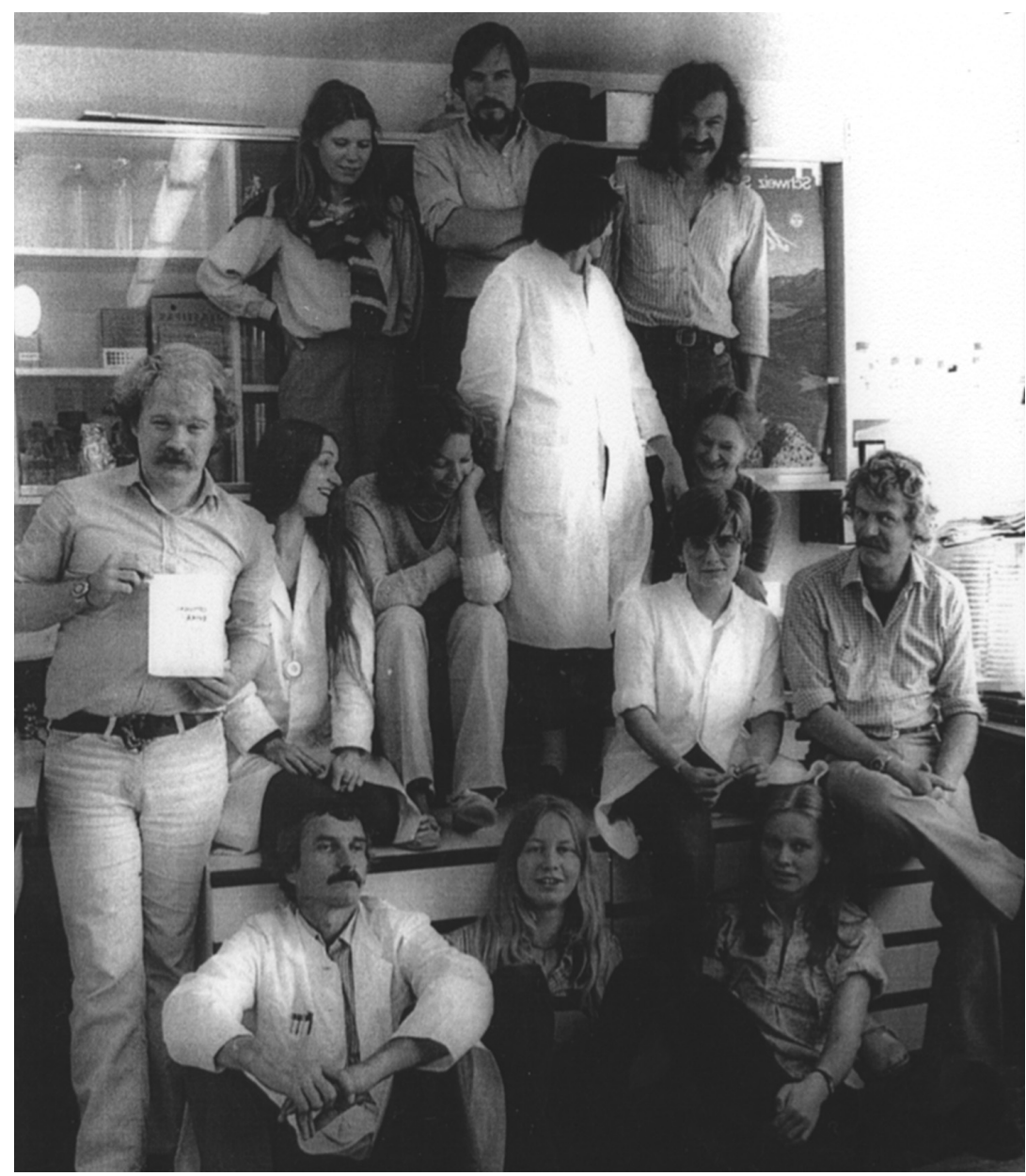

Fig. 1. Rudolf Jaenisch in $\mathbf{1 9 8 0}$ (first on the right, middle row) with members of his laboratory in Hamburg.

establish everything new and we began to generate many strains of transgenic mice. It soon became clear that Koprovski was not correct; the viruses were not expressed in the early embryos. I tried everything. But when I infected embryos with virus at gastrulation, just a few days later, they were highly expressed. It appeared that the stage of development determined whether embryos would or would not express the viruses. This was a big puzzle that needed an explanation. When we looked at DNA methylation, it became clear that there was a tight correlation: infection of cleavage embryos leads to methylation and silencing of the virus, whereas the virus remained unmethylated and was expressed when infecting later stage embryos. It was clear that sensitivity to virus replication and de novo methylation were developmentally regulated. This was really interesting but it was only a correlation. I only worked with retroviruses because these viruses were so efficient in infecting embryos. My main interest was: what was the mechanism of virus silencing? I could only address this question at Whitehead when this terrific Chinese student En Li joined my lab.

\section{So what year was this?}

I was in Hamburg until 1984 when I got the offer to come to Whitehead and MIT.

\section{How did you get the offer here?}

I knew David Baltimore as he had communicated my Moloney papers to PNAS and was well aware of my work. David, as the founding director, started the Whitehead Institute in the early 1980s. He is one of the most visionary scientists I have met and I was very excited when the possibility came up to join the Whitehead Institute and MIT. I got an offer and started two weeks after the Institute opened. I moved my big mouse colony from Hamburg to Boston, a major headache, and I am here since 1984. It is a place that is difficult to leave.

\section{And you have managed always to be at the top of the wave, which is amazing.}

I continued to work with viruses as they are really useful reagents to probe into development. But what really got us into epigenetics was this student En Li. He generated our first embryonic stem (ES) cell lines, the J-1 ES line that has been used by many people to make knock-out mice. And then he made the first knockout of a key enzyme for epigenetics, the DNA methyltransferase Dnmt1.

\section{That's the one you wanted right?}

Right. The mutant mice were really informative. I mean, it allowed us to study epigenetics by genetic means.

\section{Was this the Cell paper?}

Right (1992). The mutant allowed us to study the role of methylation in cancer, $\mathrm{X}$-inactivation, imprinting...

\section{1,220 citations as of this morning.... What made} you think you had to knockout this gene (Dnmt1)?

Well, Tim Bestor, then at Harvard, had isolated the enzyme and shown that it methylated DNA in vitro. But what was the function of methylation in animals? The paper showed that mutant mice would die early after gastrulation demonstrating that methylation is essential for mammalian development.

\section{There were so many genes and enzymes that you could have knocked out...}

Right. Yes, but this was clearly an important enzyme, the first one known to be important for DNA methylation. Before this mutation was made, people correlated methylation changes with developmental gene activation or with diseases such as cancer. For two decades, these were mere correlations that did not allow a causal connection to be made. The mutant mouse strain for the first time allowed us to use a genetic approach to make a causal connection: DNA methylation was crucial for normal development, was the basis for genomic imprinting, was a key mechanism in X chromosome inactivation and strongly affected cancer. We worked on all of these issues. These experiments convinced me that epigenetics is a key mechanism in development and differentiation. Then Dolly came up arguing that nuclear transplantation would be the most unbiased way to study epigenetics.... 


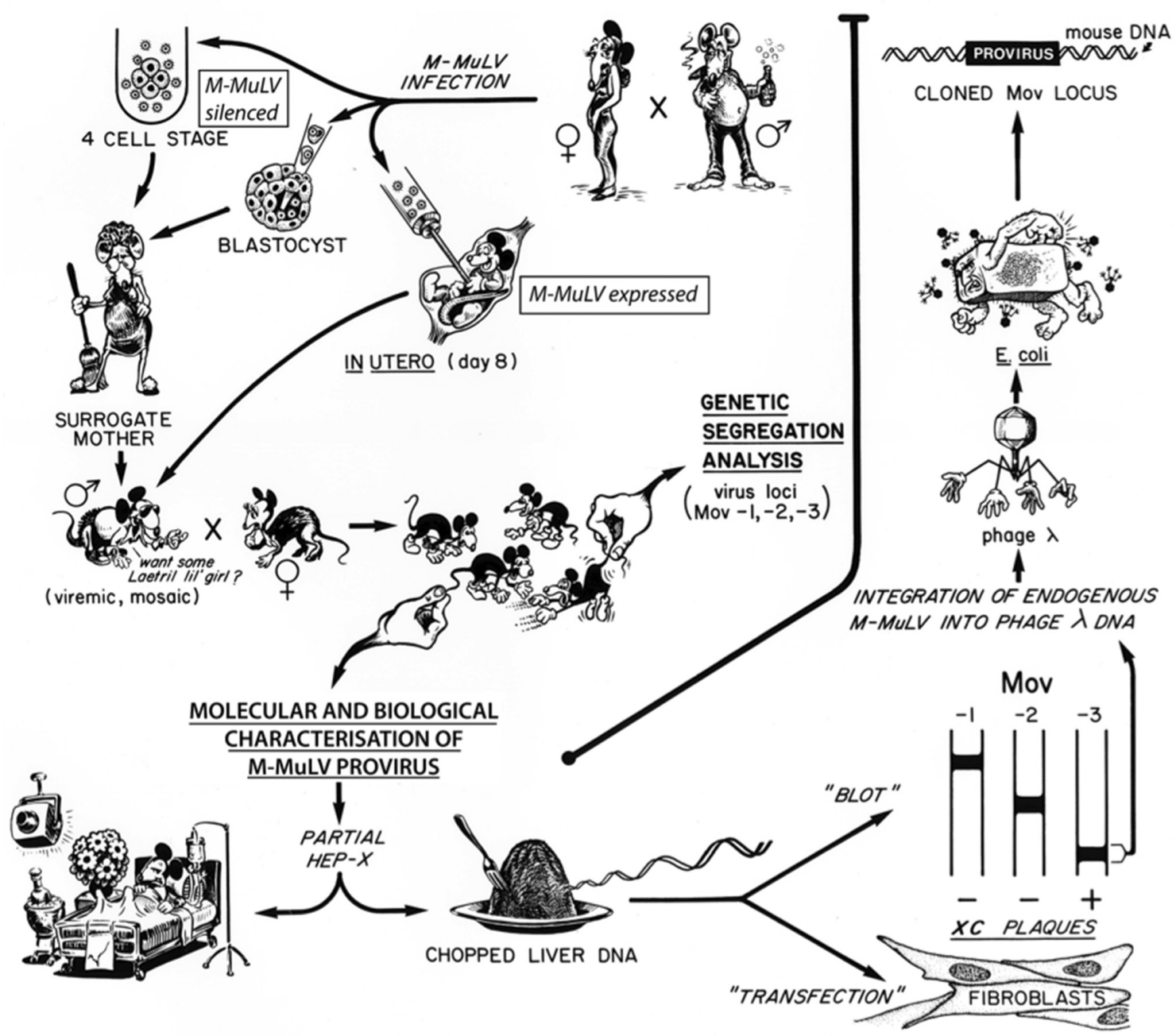

Fig. 2. Scheme of inserting exogenous Moloney leukemia virus (M-MuLV) into the germ line of mice. Embryos were infected with M-MuLV either at the 4 cell stage, the blastocysts stage or in utero at around gastrulation (E 8). The virus was efficiently silenced in preimplantation embryos, but highly expressed 5 days later at embryonic day 8. Infected cleavage stage embryos were transferred to a foster mother. The resulting offspring was viremic and mosaic, i.e. carried M-MuLV sequences in part of their somatic cells. To test for germ line integration, the mice were crossed with normal animals, the offspring were subjected to partial hepatectomy and DNA was isolated. The presence of viral sequences was detected by Southern blot analysis and by a plaque assay (the XC assay). In order to isolate the proviral integration locus, the DNA was molecularly cloned by insertion into phage I followed by infection of E. coli. (based on Jaenisch (1976), Proc. Natl. Acad. Sci. USA 73: 1260-1264; Jaenisch et ai, (1981) Cell 24: 519-529). Drawing by Jamie Simon, Salk Institute.

If I want to ask you what the theme of your career is, what is it? ... and do not say epigenetics...

I would say 'curiosity in development': how does an egg become an animal? The viruses were really just probes allowing us to study mechanisms of gene silencing and nuclear reprogramming. At the time, SV40 was a tool to probe DNA replication in eukaryotic cells. When we discovered that Moloney virus could become part of an animal's genome, it became clear to me that one could use the virus as a tool to probe mammalian development.

\section{When did you get interested in Rett's Syndrome?}

Rett syndrome is a very interesting disease. It is caused by mutation of Mecp2, a DNA methyl-binding protein that recruits silencing factors. The gene had been knocked out by Adrian Bird resulting in a lethal phenotype. When a postdoc in my lab
- Richard Cheng - knocked out Mecp2 he found, in contrast to Adrian Bird, live mice. He was crushed assuming that he messed up his construct. When we looked at the animals I noticed that they were oversized, shaking and not very happy.

\section{How old were these animals?}

They were four weeks of age. I advised Richard to "kill them today before they die" but he wanted "to see what is happening with them". The next day they were dead and he figured out that they developed symptoms very similar to patients with Rett.

\section{Were they females?}

No, those were males, the females live longer. We used these mice to study the molecular biology of Rett and how to improve the symptoms. 
Have you ever gotten scooped by other scientists?

Oh yes, sure but in this case Adrian Bird's mutant ES cells had another alteration causing lethality. He made the correct mutation at the same time as us and we published side by side.

\section{So you said sometimes you got scooped by other people? Oh sure.}

\section{So what do you do then?}

Oh well you talk to the people in the lab and encourage them to solve the next problem.

I'll give you a clear example. You published a PNAS paper two or three years before Yamanaka reported induced pluripotent cells. And you mentioned that we should all be looking at OCT4 and proteins that have similar domains that maybe important for reprogramming. People, including me, thought that you had gone crazy; it was too simplistic an approach. Then Yamanaka came out and it turns out that your were somehow on the right track... that's got to hurt?

Yamanaka is interesting because we had the same ideas. Yamanaka used the pluripotency factors Oct4 and Sox2 for reprogramming, an approach that was rather obvious from what was known at the time. But I was most impressed by two aspects of his approach: first, using 20 viruses at the same time to introduce the candidate genes - I think this was a bold experiment and only worked because he had such a strong selection. Secondly, the use of the two oncogenes C-myc and Klf4 was ingenious: it increased the efficiency of reprogramming ......

To push the cells forward...

Yes, this way he could detect the reprogrammed cells. You don't need to use the oncogenes, but they made reprogramming so much more efficient. It was clear when his 2006 paper came out that these were not really ES cells, they were only partially reprogrammed.

\section{We saw that in Toronto (2006).}

Yes, at the ISSCR meeting in Toronto. The original iPS cells couldn't make chimeras and they did not activate the endogenous Oct4. We were thinking along similar lines, had generated all the reagents, and when his paper came out we were in a good position to repeat and modify the approach. In 2007, three labs, those of Yamanaka, of Hochedlinger and my lab showed that iPS cells were indistinguishable from ES cells and could contribute to the germ line. Because three independent labs came to similar conclusions, people had to believe it.

Right. So what do you say to the person in your lab that was two years working on the reagents and gets scooped?

Well I say, let's go to the next step. There are so many unanswered question in direct reprogramming - just as there were in nuclear cloning. When Wakayama published the first cloned mouse, I was very excited because nuclear cloning appeared to be the most unbiased way to study epigenetic reprogramming. I immediately set up a collaboration with Wakayama and Yanigamachi to study epigenetic events such as $\mathrm{X}$ chromosome reactivation and imprinting in cloned mice. Yamanaka's experiment raised similar questions.
Yes, well that's too recent. Tell me more about the Rett syndrome stuff. So after you've got the mice...

When we analyzed the mutant mice they had a strikingly similar phenotype to girls with Rett and it seemed extremely rewarding to learn about the human disease by studying the mice. Rett Syndrome is the most frequent cause of mental retardation affecting 1 in 10 to 12 thousand girls. It's an awful disease. My research was supported in part by the Rett Foundation. The Foundation was run by women with a Rett daughter who devoted their life to caring for their child and to raise money for research - truly remarkable. I was really impressed seeing the Rett girls wringing their hands and the mutant mice wringing their paws. Also, the changes in the brains of patients and mice were very similar making the mutant mouse a very relevant model to study the disease. Rett research is a very active field with substantial progress in understanding the pathogenesis. I decided to leave the field because I felt my lab was too thinly spread.

\section{So... that's something we need to learn too, when we think we are spreading too thin...}

Yes . I made similar decisions in the 90s. I had terrific postdocs in the lab working on topics such as muscle development (we made the first mutations of MyoD, Myf5), on neural development (mutations of Bdnf, NT3, NT4, p75), on Wilms tumors (Wt-1) or on $X$-inactivation (Xist mutation). When they left my lab to set up their independent labs, I felt I should (and could) not compete with them and got out of these fields. They all have done extremely well. However, I wouldn't want to get out of the reprogramming field, even if there was a potential overlap with former students or postdocs.

So you felt in love with reprogramming...

Yes, that's why I didn't get out of this field. I do not think, however, that overlap in the approaches is a problem as there are so many interesting questions to be answered.

I don't really think we have found the way the egg does it yet...

No, I agree with you. We are getting insights into the mechanisms of direct reprogramming, but we have not learned as yet how the egg cytoplasm accomplishes the reprogramming of a somatic nucleus after nuclear transfer.

The funny thing is that the egg needs a genome like the gametes, to do it right most of the time, and we get lucky with it sometimes with the nucleus of a somatic cell... But how do you find the right cell? So we don't know yet.

I think a key difference became apparent with the Boiani and Schöler experiment where they showed that an Oct4 transgene becomes activated in the four cell cloned embryo, which is much faster than in direct reprogramming where the endogenous Oct4 gene is only activated after many cell divisions. This tells you: there are very different mechanisms in nuclear transfer and in the iPS approach.

\section{Plus there's so many changes that chromatin goes through...} so many....

Yes, in vitro reprogramming requires multiple rounds of DNA replication - that is when chromatin changes and DNA modifications can happen. 
Now do you think that when we do iPS, its as fast as one cell division or does it take longer... My question is, is it because we cannot pick it up earlier, because we do not have the tools yet to see that there are multiple cells in the culture, but we don't see them?

The issue is: can we recognize intermediate stage cells that are not as yet fully reprogrammed? Markers such as alkaline phosphatase or SSEA1 can be used, but these markers are expressed on many cells that never develop into an iPS cell and thus are not a stringent criterion for an iPS cell. Also, it takes many rounds of cell division before iPS cells appear in a culture that has been transduced with the reprogramming factors. Reprogramming is a stochastic process and it is not possible to predict whether or when a given cell will turn into an iPS cell. Jacob Hanna in my laboratory analyzed the kinetics of reprogramming and the effect of p53 deficiency. He showed in a Nature paper last year that every somatic cells, he used pro B cells, has the potential to produce an iPS daughter cell, but it may take many cell divisions.

\section{So what do you measure then?}

In most studies, the efficiency of reprogramming is defined as the fraction of cells; most often MEFs are used as the starting cells that become iPS cells at some arbitrary point after factor induction. This, combined with the often unknown level of cell death and the high frequency of sibling iPS colonies that can be derived from the same infected cell makes the determination of "reprogramming efficiency" problematic. In addition, virus mediated gene transduction to initiate the reprogramming process is inefficient and creates genetically different cells (because the cells carry different proviral copies). We have tried to avoid some of these complications by using a "secondary system", i.e mice carrying integrated, lenti-doxycyclin inducible viruses. From these mice we can isolate any cell type, add DOX and generate secondary iPS cells without the need for virus infection. We have defined "reprogramming efficiency" as the potential of a somatic cell to generate at some point an iPS daughter. Such an experiment is difficult to do with MEFs because they are heterogeneous, have a low cloning efficiency and senesce.

In contrast to most studies that used MEFs, we used pro B cells that have an extremely high single-cell cloning efficiency, are genetically homogenous (they have undergone heavy Ig chain gene rearrangement) and do not require immortalization. Using "secondary" pro B cells, we could show that all somatic cells have the potential to generate iPS daughter cells by a stochastic or probabilistic process. We used this system to study the influence of p53 deficiency on reprogramming. Last year, five papers in Nature reported that p53 inhibition in MEFs increases reprogramming efficiency by between 4 and 100 fold. This substantial difference in reprogramming efficiencies in the different studies likely reflects how difficult and arbitrary it is to make such measurements in MEFs. Using the secondary pro B cells, we came to a different result.

\section{What was the result?}

Our result was very clear: p53 inhibition does not increase efficiency as measured in our experimental paradigm using the potential of single pro B cells to generate iPS cells, but rather shortens the time until all clonal populations have generated iPS cells. We found that p53 deficiency increases the proliferation rate. Most importantly, when the results are plotted not against the time of factor expression, but against the number of cell divisions, both curves collapse into one. This indicates that iPS cells appear in p53 deficient and wild type cells after exactly the same number of divisions, suggesting that cell cycle is the key parameter for epigenetic reprogramming.

\section{Are you saying that you could clone by SCNT from $95 \%$ of the cells?}

No, the success rate of reprogramming by SCNT is very low and depends on the criteria for success by SCNT - if it is activation of the somatic Oct4 gene it would be much higher. For the generation of iPS cells, the process is stochastic or probabilistic: you never can predict in a population whether a given cell will turn green and when being green means that the cell is reprogrammed to pluripotency.

\section{So how soon would you get iPSC?}

There is a lag period of 10 to 14 days before the first iPS cells appear.

\section{And... yet, it is two days in the egg in the mouse.}

It is only one or two divisions of the cloned mouse embryo, as based on the Boiani - Schöler experiment with Oct4 activation. I think that mechanisms involved in SCNT and in iPS cell formation are totally different. It is an interesting and unresolved question why reprogramming by SCNT is so rapid as compared to direct reprogramming.

The time flew by so quickly that when I realized that I had not asked any of the questions I had prepared, I tried to switch gears and selfishly started asking questions about dealing with day-to-day issues as a scientist...

According with the latest NIH statistics, in the 70's a new PI got the first R01 when she/he was in his 30s; now is in her/his 40s. When I wrote my first grant I was at the Salk Institute and proposed to make transgenic mice (the name had not been coined at that time).

Was your expertise unique?

No, I did not have track record for this experiment and it was

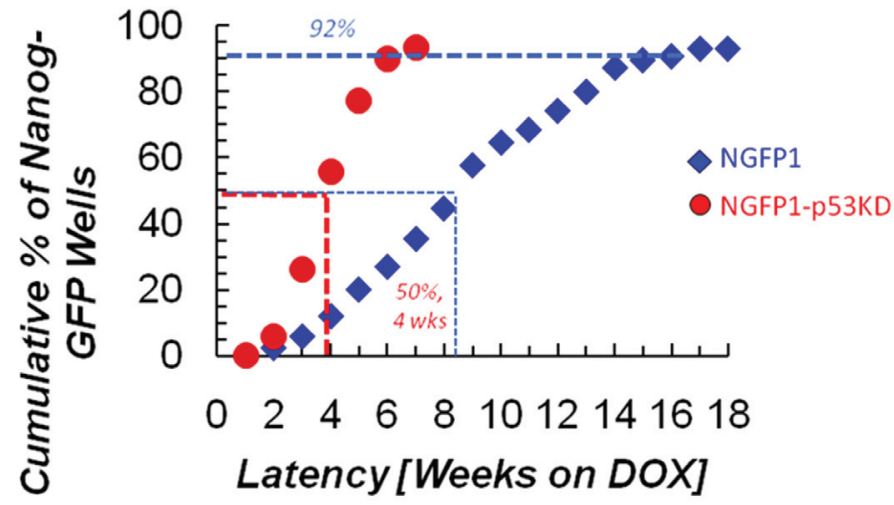

Fig. 3. Effect of p53 inhibition. P53 inhibition does not increase the fraction of $B$ cells generating iPS cells, but accelerates reprogramming kinetics. 
highly risky. The study section consisted of people like Mike Bishop and I got the grant immediately. I think these were really different times. Study sections were willing to support high-risk projects. Think about how decisions are being made today. Study sections want to see preliminary data and they are not likely to support high-risk projects. When you start your career, if you do not have good supporting data or if you want to get into unchartered territory, it may be difficult to get funding and this may badly affect your career. I never thought about my career, but rather proposed what I found interesting and what I really wanted to do.

\section{But it just so happens that what you chose was high risk...}

These initial experiments were risky as they never had been done before. But the study section bought it. Later, when I saw the Wakayama paper on the first cloned mouse, I decided that nuclear cloning is the most unbiased way to study epigenetic reprogramming. But I did not have the money to do SCNT. I went to the director of the Whitehead and said 'I need the money for this now, I cannot wait', and he replied 'give me 5 minutes' and I got what I needed!

But you kept on taking risks ....you could have said well... I will keep doing my own stuff, my Rett syndrome stuff, but you did not do that, you felt in love with cloning and just did it?

Yes, I could do this because I was relatively well established. But can you afford this when you start a new lab? No. I could afford it because I was supported.

So the guy is turned down, the new PI; what do you tell them when they are running out of start-up money? Or when they are going up for tenure?

This is one of the problems in our system, because of funding and because of competition. NIH will often fund bandwagon type of projects that have a high chance of success and unless you have preliminary data you have little chance to get it and that is a problem. When I started my career, study sections took risks, like with me!

\section{Was it because they had more money to give?}

I think there were proportionally fewer applications and a different philosophy for funding.

\section{Are we training too many PhDs? Do we have too many PIs?}

Well it appears that science is growing faster than the funds we have available. This is a serious issue, but it would be inappropriate to argue that we have too much science (chuckles).

\section{Back in the 70s were there more PIs at the bench?}

I think young PIs were always at the bench. I love to work at the bench. There are certain things that I can still do.

What would you like to do if you were back at the bench?

People in my lab are better at everything. One exception is that I can manipulate post implantation embryos and inject them in utero with cells or viruses. This was, actually, the very first experiment I did went I came to the Whitehead. I thought that I needed to do something myself and still worried about the 17 stripes in the chimeras reported in the 1967 Mintz paper where she concluded that the 17 stripes on each side of the chimeras were derived from 17 primordial melanoblasts originating from neural crest cells after emigrating from the neural tube. I decided to test the model and isolated neural crest cells, explanted the neural tubes from $\mathrm{E} 8$ days C57/B6 embryos and declared that any cells growing out of the tubes must be neural crest cells - at this time there were no markers for these cells. I collected the few cells I could isolate, maybe a thousand or fifteen hundred in total, and microinjected them in utero into 8.5 day albino embryos, a time point which corresponds to the time when neural crest cells leave the neural tube. I did not think that the experiment would ever work. But I still remember, it was late in the evening, when I checked the mouse house and saw that 3 of these 7-day-old pups had black heads, it just blew me away. Clearly, the injected cells had somehow found their way to colonize the pigment system of the embryos. Coming back to the Mintz paper, why did she get 17 stripes? It did not make much sense. Her explanation was that one stripe was colonized by one founder melanoblast, but why would there ever be black and white stripes alternating? Statistically this should happen in 1 in a million and she did not look at a million mice but may be at 50 . So this is why her conclusion never made 
sense to others in the field. I convinced a postdoc to test her model and do the experiment differently. Because this is a fate mapping experiment you need to label the primordial melanoblast when they leave the tube. The experiment I suggested was to inject a viral vector carrying the tyrosinase gene, the gene that is mutated in albino mice, into albino $\mathrm{E} 8.5$ embryos, just the time when the neural crest cells are thought to migrate from the neural tube and colonize the epidermis. The question was: could we introduce a virus into one of these albino melanoblasts and induce its potential to make pigment. The key question was: how wide is the stripe? We got adult mice that had a single stripe! And the width of the stripe was not very different from Mintz's. The interpretation was that Mintz was basically right though I still do not understand why she obtained the result she got.

If you could do anything, at the bench, what would you do? I went on sabbatical in the 90s to Germany. I wanted to learn all sort of things on genomics and microarrays, I did many PCRs and was very frustrated when, at the end of an experiment, I was not sure whether I had added the enzyme or DNA to a given tube or not. I must say, this gave me a good perspective how tough it is to do molecular biology! I realized that I would be pretty bad at doing these experiments myself. It is very important to talk with people in the lab and to make suggestions. I talk almost with everybody in the lab nearly every day and discuss the progress. Often my suggestions turn out to be pretty stupid and we argue, sometimes they may be helpful - I find that such arguments are very healthy. I can judge all primary data, even if I cannot do the experiments myself. And I insist that people in my lab do not cut corners and, for example, produce good Southerns to make conclusions about integrations of viruses before believing the data.

What do you do when one of your fellows in the lab comes in and says "I have a paper, I think I already have a paper" and you think it is good, but that it would be a much better paper if they do 2 or $\mathbf{3}$ more experiments. What do you do?

You argue with them and persuade them to generate convincing data.

\section{But it could take 6 more months...}

Yes, but you cannot publish data that are below your standard. The problem is that you may be scooped by mediocre papers- and I could give you many examples where this happened. This creates tension but we cannot publish below our standards, even if we get scooped.

\section{It pays to be paranoid...}

The stem cell field is moving very fast and is very competitive. It was great in the 70s when people would talk in public about the newest and possibly not yet finished experiment. When you had an interesting result you had to tell everybody and would share it immediately, it was fun.

Maybe that is what kept you all these years at the top of the wave...you basically tell your postdocs 'go and thrive' when they leave your lab. Do you ever tell them what not to do?

When they leave to set up their own lab I tell them that if we do similar things, we should talk about the projects and coordinate.
But I would never tell anyone not to do a project they are interested in.

\section{But when they leave your lab, they never know what you are} doing....!

It goes both ways. With some people it works very well and with some others less well, it depends on the personality. It is tough for some young faculty to start their career and to find their niche. I want to see them succeed and I am always happy to help.

So when you have younger kids coming for advice, right out of college with a biology degree, lets say... pre-med, and they tell you "I want to do developmental biology"; imagine the person is coming from a top $\mathbf{5 0}$ school, good grades, good letters of recommendation, where would you send them? Would you send them to a big lab?

I think that depends on the personality. At MIT new students tend to go to labs of young faculty assuming they get more attention. This is what I did. The Mintz lab was a really small lab and in the Levine lab I was the only postdoc, so it was great.

\section{So you would send them to a school where they have rotations setup?}

Well sure, but that is how MIT does it. At MIT we have three one-month rotations and the student can see whether the atmosphere of the lab and the topics fit his or her interest. I think that is a good system.

\section{But your lab is big...}

When a student comes to my lab, I try to match him up with another senior student or postdoc and join an ongoing project. This will give the new student the chance to learn the methods in the lab and gives enough time to think about a project he or she is interested in and then develop from there their own project. In general I suggest several projects. For students I like to have a bread and butter project that has a good chance of yielding results, but may not be the most exciting one. Most come up later with something that is fun but more risky, and we extensively discuss it. And then after a year or longer they may decide 'this is my thesis' and the other projects proceed as a collaboration with others. Postdocs should come up with their own ideas that fit into the labs interests. But I feel very responsible for students.

\section{Do you have weekly meetings?}

Yes, every week two people present their own data. It is important to get people talking about their work, arguing about it, and defending their experiments.

\section{A scientist no longer with us that you admire the most?}

Einstein, Darwin. But the alive ones, Levine, Mintz, Baltimore.

Is there a trap to avoid for those running for tenure; what should they avoid?

There are probably many....there is enormous pressure to get your papers out. But one should not be doing projects because they give rise to a paper; rather do that project which really excites you and assume the risk that it may not work out. This is what I did: I only took on projects which interested me, with little regard to whether they were "publishable". But I was privileged in the old 
times and could later easily switch because I had the funds. Today it is much tougher for a lab which is beginning .

\section{What do you tell them when they go out (postdocs)? Do you give them some advice?}

Yes sure. I help them how to negotiate the position. I tell them to follow their interest. But success is often difficult to predict. How much of a scientific career is just being smart and imaginative? How much is due to being at the right place at the right time? How much is due to luck? I think that in my case, there was a lot of luck.

\section{But you have to be prepared.}

Sure, but in my case, having a medical degree did not prepare me very much for doing molecular biology. I did not learn anything of this in medical school. But I think what I learned in medical school was useful as it gave give me a certain perspective for biologically relevant questions.

\section{If you were to do one thing different in Science what would you change?}

I think there are two extremes of science support. Traditionally in Germany you could get long term support to pursue possibly risky experiments. It may not matter whether you are productive or not, you may have the money (though this is changing rapidly). On the positive side, this allows you to follow your most exciting ideas, but risking total failure and never producing anything. It may allow you to accomplish something extraordinary. On the other hand, some may just do not much at all, because there may be little quality control and the pressure may not be high.

Here in the USA it is the opposite: if you are not productive you are out. So can you afford to follow risky ideas? Probably not, because of the pressure to be productive. These are two extremes and it would be nice to have a compromise between the two. As I said, Germany is changing, but in principle it would be good to give people the possibility to follow non-conventional ideas, but you need quality control.

I must say I was well supported by the NIH throughout my career; I always had my NIH grants; the peer review system despite its flaws is a great system. Although I hate writing grants, it helps you think seriously about what and why you want to do an experiment and forces you to put your thoughts into perspective.

\section{Do you like the way NIH is going now?}

No. I think the review system is overwhelmed by the number of applications combined with the lack of funds.

\section{Advantages of running a large lab and advantages of running a small one?}

I think the main advantage of running a small lab is that you are in charge of everything. A large lab like the one I run gives you a strong basis of technology. When Yamanaka published his landmark paper in 2006, we had everything in place, all the technology needed to do the experiment, combined with a large transgenic mouse colony which made it straightforward to advance the iPS field.

J. Cibelli: Well there you have it. I can only thank the editor of the Int. J. Dev. Biol. for encouraging me to have this open conversation with Rudolf, and I doubt I would have been able to ask so many naïve questions if I hadn't the excuse of an 'interview'. And I think Rudolf enjoyed it too! After all, sharing the memories of a particular event and the thoughts behind each breakthrough - and setbacks - are what can influence the new generation of scientists the most. And Rudolf does care for the future of his fellows, they will carry the positive 'imprint' of having been mentored by him, no Dnmt1 KO will ever erase that!

After more than 3 hours of conversation Rudolf still had stamina left for the next appointment, a racquetball match with a postdoc. One more message for those single minded scientists like me, i.e. do not make excuses about not having enough time to take care of yourself, if someone with more than four hundred manuscripts published - and counting - can do it, so can you!

\section{Relevant publications selected by Dr. Rudolf Jaenisch}

JAENISCH, R. AND MINTZ, B. (1974) Simian virus 40 DNA sequences in DNA of healthy adult mice derived from preimplantation blastocysts injected with viral DNA. Proc. Natl. Acad. Sci. USA 71: 1250-1254.

JAENISCH, R. (1976) Germ line integration and Mendelian transmission of the exogenous Moloney leukemia virus. Proc. Natl. Acad. Sci. USA73: 1260-1264.

JÄHNER, D., STUHLMANN, H., STEWART, C.L., HARBERS, K., LÖHLER, J., SIMON, I., AND JAENISCH, R. (1982). De novomethylation and expression of retroviral genomes during mouse embryogenesis. Nature 298: 623-628.

SCHNIEKE, A., HARBERS, K., AND JAENISCH, R. (1983). Embryonic lethal mutation in mice induced by retrovirus insertion into the $\alpha 1(\mathrm{I})$ collagen gene. Nature 304: 315-320.

ZIJLSTRA, M., BIX, M., SIMISTER, N.E., LORING, J.M., RAULET, D. AND JAENISCH, R. (1990). $\beta 2$-microglobulin deficient mice lack CD4-8+ cytolytic T cells. Nature 344: 742-746.

LI, E., BESTOR, T.H. AND JAENISCH, R. (1992). Targeted mutation of the DNA methyltransferase gene results in embryonic lethality. Ce//69: 915-926.

HUMPHERYS, D., EGGAN, K., AKUTSU, H., HOCHEDLINGER, K., RIDEOUT, W. BINISZKIEWICZ, D., YANAGIMACHI, R. AND JAENISCH, R. (2001). Epigenetic instability in ES cells and cloned mice. Science 293: 95-97.

RIDEOUT, W.M., HOCHEDLINGER, K., KYBA, M., DALEY, G., AND JAENISCH R. (2002). Correction of a genetic defect by nuclear transfer and combined cell and gene therapy. Cel/109: 17-27.

HOCHEDLINGER, K. AND JAENISCH, R. (2002). Generation of monoclonal mice by nuclear transfer from mature B and T donor cells. Nature 415: 1035-1038.

HOCHEDLINGER, K., YAMADA, Y., BEARD, C. AND JAENISCH, R. (2005). Ectopic expression of Oct-4 blocks progenitor cell differentiation and causes dysplastic growth in epithelial tissues. Cel/121: 465-472.

BOYER, L.A., PLATH, K., ZEITLINGER, J., BRAMBRINK, T., MEDEIROS, L., LEE T.I., LEVINE, S.S., TAJONAR, A., RAY, M.K., WERNIG, M., OTTE, A., VIDAL, M., YOUNG, R.A. AND JAENISCH, R. (2006). Polycomb complexes repress developmental regulators in murine embryonic stem cells. Nature 441: 349-353.

WERNIG, M., MEISNER, A., FOREMAN, R., BRAMBRINK, T., KU, M., HOCHEDLINGER, K., BERNSTEIN, B.E. AND JAENISCH, R. (2007). In vitro reprogramming of fibroblasts into a pluripotent ES-cell-like state. Nature 448: 318-324.

HANNA, J., WERNIG, M., MARKOULAKI, S., SUN, C-W., MEISSNER, A., CASSADY, J., BEARD, C., WU, L-C., BRAMBRINK, T., TOWNES, T. AND JAENISCH, R. (2007). Treatment of Sickle Cell Anemia mouse model with IPS cells generated from autologous skin. Science 318: 1920-1923.

WERNIG, M., ZHAO, J.P., PRUSZAK, J., HEDLUND, E., FU, D., SOLDNER, F., BROCCOLI, V., CONSTANTINE-PATON, M., ISACSON, O., JAENISCH, R. (2008b). Neurons derived from reprogrammed fibroblasts functionally integrate into the fetal brain and improve symptoms of rats with Parkinson's disease. Proc Natl Acad Sci USA 105: 5856-5861.

HANNA, J., MARKOULAKI, S., SCHORDERET, P., CAREY, B.W., BEARD, C. WERNIG, M., CREYGHTON, M.P., STEINE, E.J., CASSADY, J.P., FOREMAN, R., LENGNER, C.J., DAUSMAN, J.A. AND JAENISCH, R. (2008). Direct reprogramming of terminally differentiated mature B lymphocytes to pluripo,tency. 
Cel/133: 250-264.

HANNA, J., SAHA, K., PANDO, B., VAN ZON, J., LENGNER, C.J., CREYGHTON, M.P., VAN OUDENAARDEN, A. AND JAENISCH, R. (2009). Direct cell reprogramming is a stochastic process amenable to acceleration. Nature 462: 595601.

HOCKEMEYER, D., SOLDNER, F., BEARD, C., GAO, Q., MITALIPOVA, M., DEKELVER, R.C., KATIBAH, G.E., AMORA, R., BOYDSTON, E.A., ZEITLER, B., MENG, X., MILLER, J.C., ZHANG, L., REBAR, E.J., GREGORY, P.D., URNOV, F.D. AND JAENISCH, R. (2009). Efficient targeting of expressed and silent genes in human ESCs and iPSCs using zinc-finger nucleases. Nature Biotech. 27: 851-857.
SOLDNER F., HOCKEMEYER D., BEARD C., GAO Q., BELL G.W., COOK E.G., HARGUS G., BLAK A., COOPER O., MITALIPOVA M., ISACSONO., JAENISCH R. (2009). Parkinson's disease patient-derived induced pluripotent stem cells free of viral reprogramming factors. Cel/ 136: 964-977.

LENGNER, C.J., ERWIN, J.A., GIMELBRANT, A.A., CHENG, A.W., GUENTHER, M.G., WELSTEAD, G.G., ALAGAPPAN, R., FRAMPTON, G.M., XU, P., POWERS, D., BARRETT, C.B., YOUNG, R.A., LEE, J.T., JAENISCH, R. AND MITALIPOVA, M. (2010). Derivation of pre-X inactivation human embryonic stem cells under physiological oxygen concentrations. Cel/872-883.

HANNA JH, SAHA K. AND JAENISCH, R. (2010). Pluripotency and cellular reprogramming: facts, hypotheses, unresolved issues. Ce//143: 508-525. 


\section{Further Related Reading, published previously in the Int. J. Dev. Biol.}

See our recent Special Issue Placenta edited by Joan S. Hunt and Kent L. Thornburg at: http://www.ijdb.ehu.es/web/contents.php?vol=54\&issue=2-3

The quest for hematopoietic stem cells in the embryo. An interview with Françoise Dieterlen-Lièvre Thierry Jaffredo and Charles Durand Int. J. Dev. Biol. (2010) 54: 1075-1078

Developmental hematopoiesis: historical background and perspectives. An interview with Nicole Le Douarin Charles Durand and Thierry Jaffredo

Int. J. Dev. Biol. (2010) 54: 951-954

Contemporary comparative placenta research - an interview with Allen Enders

Kent L. Thornburg and Joan S. Hunt

Int. J. Dev. Biol. (2010) 54: 231-236

Ontogeny of an adventurous mind: the origin of Antonio García-Bellido's contributions to developmental genetics Alain Ghysen

Int. J. Dev. Biol. (2009) 53: 1277-1290

Idealism and romantic patriotism for science - an interview with José Francisco David-Ferreira Maria Carmo-Fonseca and José Francisco David-Ferreira

Int. J. Dev. Biol. (2009) 53: 1273-1275

Regeneration and pattern formation - an interview with Susan Bryant Michael K. Richardson and Cheng Ming Chuong

Int. J. Dev. Biol. (2009) 53: 827-833

Skin, cornea and stem cells - an interview with Danielle Dhouailly

Cheng-Ming Chuong

Int. J. Dev. Biol. (2009) 53: 775-782

Molecular tools, classic questions - an interview with Clifford Tabin

Michael K. Richardson

Int. J. Dev. Biol. (2009) 53: 725-731

The Hox Complex - an interview with Denis Duboule

Michael K. Richardson

Int. J. Dev. Biol. (2009) 53: 717-723

5 yr ISI Impact Factor $(2009)=3.253$
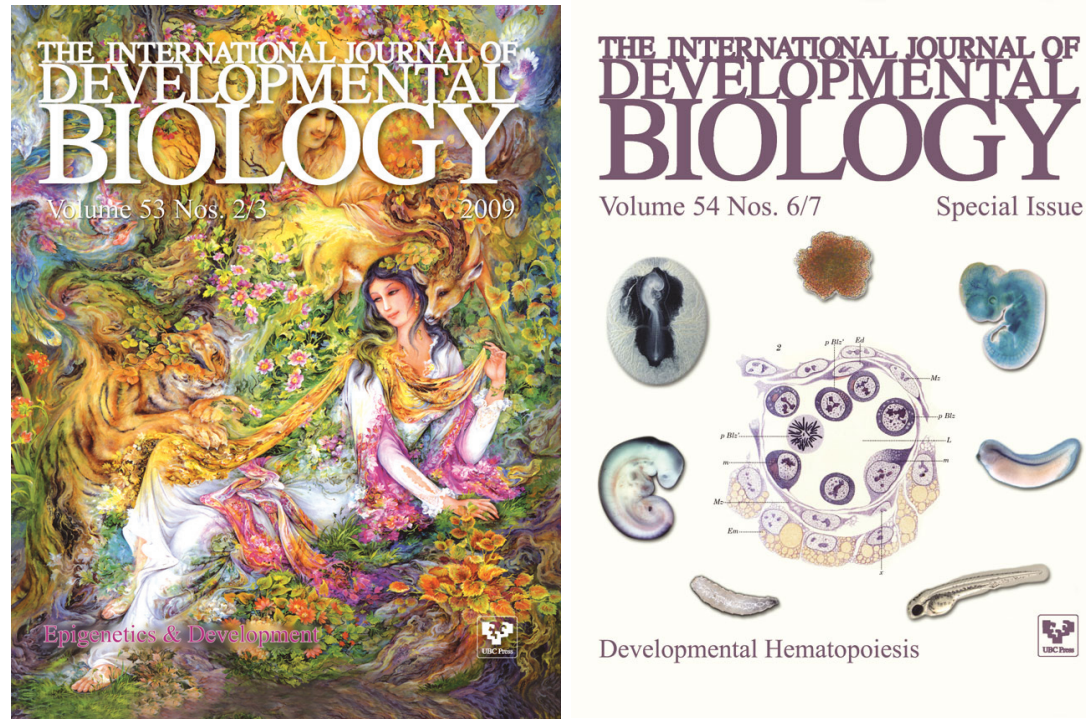

Volume 54 Nos. 6/7

Special Issue
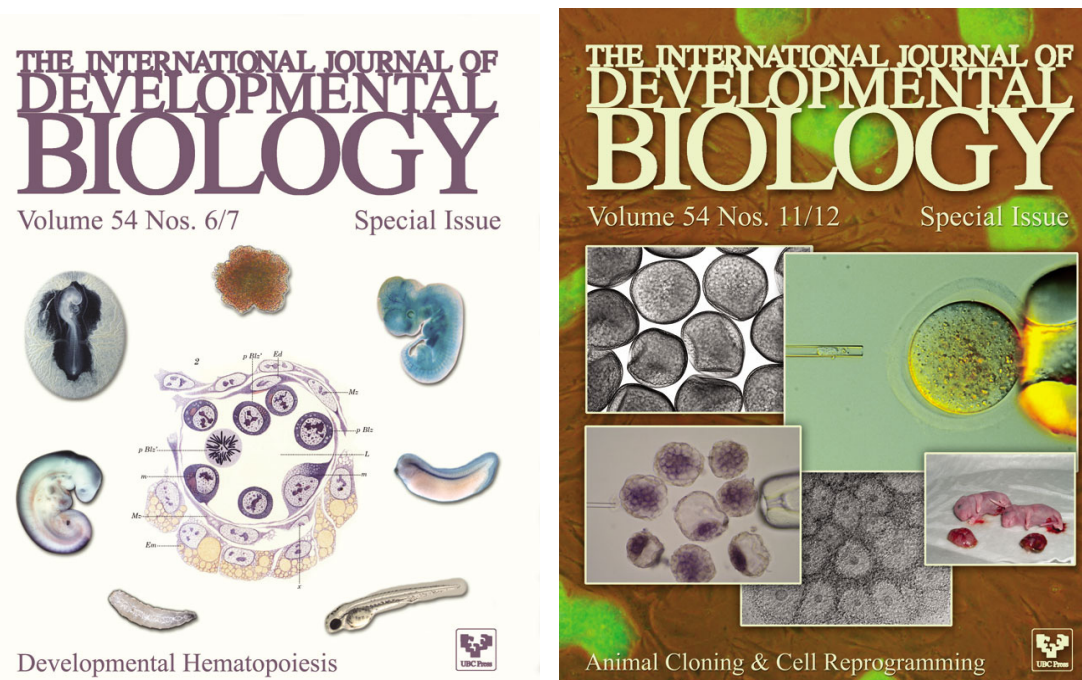

Volume 54 Nos. 11/12

Special Issue

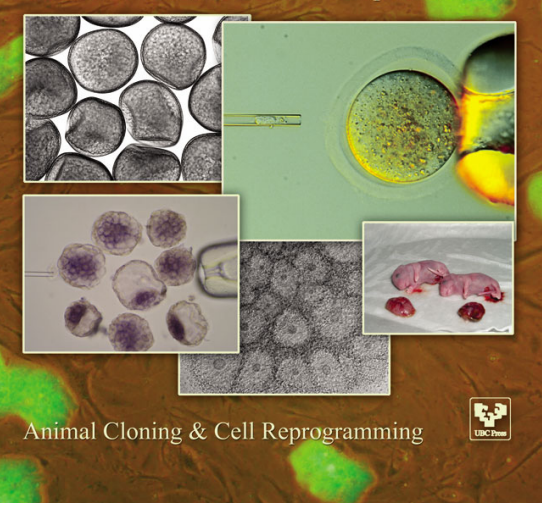

Developmental Hematopoiesis 